\title{
Quality of Islamic Leadership and Organizational Performance within the Takaful Industry in Malaysia: A Conceptual Study
}

\author{
Wan Norhayate Wan Daud ${ }^{1}$, Marlisa Abdul Rahim ${ }^{1} \&$ Aizzat Mohd Nasurdin ${ }^{2}$ \\ ${ }^{1}$ Faculty of Economy and Management Science, Universiti Sultan Zainal Abidin, Terengganu, Malaysia \\ ${ }^{2}$ School of Management, Universiti Sains Malaysia, Penang, Malaysia \\ Correspondence: Marlisa Abdul Rahim, Faculty of Economy and Management Science, Universiti Sultan Zainal \\ Abidin, Terengganu, 21300, Malaysia. Tel: 60-19-381-3887. E-mail: marlisa_rahim@yahoo.com
}

Received: August 4, 2014 Accepted: September 2, 2014 Online Published: October 30, 2014

doi:10.5539/ass.v10n21p135 URL: http://dx.doi.org/10.5539/ass.v10n21p135

\begin{abstract}
Successful organizations represent a key ingredient for nations around the globe. Although a substantial body of research has focused on the predictors of organizational performance, studies involve its predictors within the context of developing Muslim countries like Malaysia is rather limited. This study aims to contribute the understanding of Islamic leadership qualities concept in the developing countries through the exploration of Takaful performance in Malaysia. The phenomenon of Islamic leadership qualities and performance of the selected Takaful industry leaders will examine through the perspective of literacy coaches within their real-life setting using multiple sources of evidence. Thus, multiple case study method is suitable and will use in this study. Islamic Leadership Theory will extend by emphasizing factors that contribute to the success of organizational performance. The study expects that Islamic leaders will bring the organizations closer to make improvement in meeting the goal set. Furthermore, an increase in organizational performance will effect positive economic growth and enhance employees' motivation to perform better in future. The anticipate findings will reveal that the organizational performance can be enhanced by stimulating the quality of Islamic leadership. It gives an idea to managerial that Islamic leadership qualities act as a tool in helping the organizations to continue interact with stakeholders, establishes new and strong partnerships, identify future opportunities and develop the capabilities to increase organizations performance.
\end{abstract}

Keywords: quality of Islamic leadership, organizational performance, Takaful industry, Malaysia

\section{Introduction}

Performance of organization becomes a vital focus of every business organization. Organizational performance is the ability of an organization to achieve its goals and objectives (Ricardo \& Wade, 2001). By referring to past scholars, there were two dimensions of organizational performance include financial and non-financial performance (Venkatraman \& Ramanujam, 1986; Shen \& Cannella, 2002; Behery \& Paton, 2008; Ismail, Alhabshi, \& Bacha, 2011). Both financial and non-financial performances are important in determining the success of organizations. Kasturi (2006) noted some elementary differences between financial and non-financial performance measures. Financial performance defined as the economic outcome, such as market share and profitability (Delaney \& Huselid, 1996). Generally, financial performance measured in terms of profitability, return on sales, return on equity, return on investment and return on assets. Meanwhile, non-financial performance defined as the effectiveness of behavior to enhance productivity in organization (Abbasi, 2008). For instance, the non-financial performance may be measured by assessing managerial performance.

The financial services sector in Malaysia such as banks, insurance/takaful companies, brokerages and investment management firms have been emphasized as one of the National Key Economic Areas (NKEAs). The aspiration of the Malaysian government towards the Takaful industry is to create a comprehensive and progressive Islamic financial system that contributes significantly to the effectiveness and efficiency of Malaysian financial sector (Yazid, Arifin, Hussin, \& Daud, 2012). Malaysia is currently the third largest Takaful market globally with an 11\% market share, most of which is domestic-based (Economic Transformation Programme, 2012). However, the Takaful industry in Malaysia still suffers in terms of financial or non-financial performance (Halim, 2012). In a recent research conducted by Ernst and Young (2012), shareholder's returns on equity of conventional insurance companies are higher than the Takaful shareholder's returns in Malaysia. The average return on equity for 
insurance companies and Takaful operators in Malaysia was 17\% and 4\% respectively. In terms of return on investment, Takaful operators showed lower investment returns than conventional insurance companies with a $12 \%$ of return on investment of insurance companies and an $8 \%$ of return on investment for Takaful operators. These figures showed that the financial performance of Takaful operators has not yet achieve optimum business volume compared to the conventional insurance companies in Malaysia. Given the rise in competition and the need for Takaful operators to achieve competitive advantage, a few studies have tried to investigate the relevant predecessors of Takaful performance such as individual factors (Saad, Majid, Yusof, Duasa, \& Rahman, 2006; Saad, 2012; Yazid et al., 2012) and organizational structure (Rahman, 2009). However, there is unexplored research area such as the quality of Islamic leadership that may influence organizational performance of Takaful operators.

The growth in Takaful demand has put increasing pressure on the supply of high leadership quality (Halim, 2013). This issue is affecting the Takaful industry and momentum to drive the industry into the future. With the continuing growth of Takaful demand in the Gulf Cooperation Council (GCC), Indonesia, Africa and the increasing interest in Europe and North America, there is an even more pressing need to develop the quality leaders and followers' skills and competencies on a global basis.

Research on the leadership and performance among Takaful industry had carried out by many researchers (Hashim \& Khairuddin, 2012; Shooshtarian \& Amini, 2012; Hamid \& Rahman, 2011). In order to progress in the Takaful industry, the Muslim leaders of global business world must possess quality of Islamic leadership skills to survive in the competitive market. In today's demanding and dynamic leadership requirement, leaders who are incompetent in an organization must be willing to upgrade their skills (Ather \& Sobhani, 2007). It is important because Takaful industry deals with organization Islamic management from the perspective of the knowledge acquired. It revealed that Islamic basis of knowledge and outcomes in applications companionable with the Islamic beliefs and practices (Kazmi, 2007).

Although, Islamic leadership is important in organizational improvements, however, the quality of Islamic leadership practiced by its leaders still has some shortcomings in both theory and practice of Muslims' human resources (Ather \& Sobhani, 2007). Studies related to the quality of Islamic leadership and its relationship with organizational performance in the service industry such as Takaful in Malaysia context has been scarce (Mahadi, 2011). Thus, the objective of the current paper is to review the existing literature relating to the quality of Islamic leadership and performance of organizations within the Takaful industry in Malaysia. Therefore, this paper is organized as follows: first, a summary of the underlying theory; second, a review of the literature on organizational performance and quality of Islamic leadership is provided; third, propose on methodology; and finally, the implications and conclusion of the paper.

\section{Literature Review}

\subsection{Underlying Theory}

Islamic Leadership Theory is founded by spiritual traits and practices (Aabed, 2005). There are five pillars of Islam namely (i) bearing witness that there is no God but Allah (SWT) and Muhammad (SAW) is His prophet; (ii) establishing the prayers; (iii) giving zakat; (iv) fasting during Ramadhan and (v) performing hajj. It sources of wisdom collectively structure the ethical and moral system that guides the leadership process from Islamic perspectives. These spiritual variables also shape the characteristics of a Muslim leader.

Islamic Leadership Theory has chosen as the underlying theory for the proposed model since it entails Islamic leaders and followers, spiritual variables, and leadership outcomes. Islamic leaders and followers should surrender to Allah (SWT), shariah compliance, and strive positively in terms of self-awareness, self-regulation, and self-development (Toor, 2008). The Islamic Leadership Theory suggests that the quality of Islamic leadership can positively influence the attitudes of followers and bring higher levels of satisfaction, motivation, performance, positive energy, and organizational loyalty (Aabed, 2005). It will also result in amplified fulfillment, commitment, and constructive energy on part of the leaders. However, in order to maintain Islamic leadership and organizational goal, it is advisable to get the support from stakeholders, followers, and at the same time fully comply with the Islamic teachings and principles.

In general, based on the Islamic Leadership Theory, uncertainty of leader and followers' behaviors are bound to occur. Therefore, Kasturi (2006) suggest that, in order to achieve superior performance of organization, they need to be linked with integrity as a base of follower's confidence towards a leader. Moreover, according to the Islamic Leadership Theory, the quality of Islamic leadership serves as an important human resource that offers value for organizational performance. Hence, the application of Islamic Leadership Theory will require the 
organization to observe and engage in a high quality of Islamic leadership as one of the key factor in an organization's human resource management strategy for high performance achievement.

\subsection{Organizational Performance}

Organizational performance refers to the results, product and service outcomes, or accomplishments (Bougae, 2005; Gilley \& Maycunich, 2000). Scott (2003) stated that organizational performance refers to the productivity of goods and services over which the firms executes significant control. The organizational performance construct consists of effectiveness and efficiency (Armfield, 2005). Effectiveness defined as the degree to which an organization meets the goals and its mission. Meanwhile, efficiency described as utilization of organizational resources.

From the Islamic point of view, performance implies an even extensive outlook to stimulate people for higher performance in addition to those mentioned above. Alhabshi and Ghazali (1994) defined performance as proficiency. Proficiency means efficiency, which suggests greater goods and services productivity. Proficiency is a feature that implies each organizational member will carry out his/her job responsibilities well. From the management point of view, Abbasi (2008) defined performance as proficiency (ihsan) which means doing good job or doing tasks in a proficient manner. If employees in organization show good proficiency in their performance, it will increase not only shareholders' profitability, but also the value of the entire organization. As a result, the organization's stakeholders will become more satisfied.

The insurance demand or performance of Takaful has been established from past researches that various demographic and socioeconomic variable were positively recognized to be positive antecedents of insurance demand (Enz, 2000; Beck \& Webb, 2003; Fukuyama, 1995; Browne \& Kim, 1993). Yon (2004) investigates the link between the profitability of Takaful operators and macroeconomics variables as well as business variables. It found that insurance services are necessity and insurance is no longer perceived as a luxury. Although there are some changes in the economic items, the Takaful operators' profit and demands for Takaful services are still important. Rahman (2009) examines the Takaful performance by looking at the growth of the Takaful industry. Based on the study, it found that the population size and demographic factors were important aspect in contributing to the Takaful industry growth. In contrast, Mudaki, Wanjere, Ochieng, and Odera (2012) suggested that operational factors such as claims, agents and brokers, infrastructure, customer needs and marketing relate with organizational performance in Kenyan insurance industry. The results of study may not be in agreement with the normal practice in the insurance industry. It revealed that the operational factors do not affect the performance of an insurance firm significantly.

\subsection{Quality of Islamic Leadership}

Leadership in Islam is the voluntary coach and inspiring process towards followers in order to fulfill a clear and shared vision (Chowdbury, 2002; Altalib, 1991). In Islam, religious, moral, and spiritual elements dominate the leadership of Prophet Muhammad (SAW) and the four Caliphs (Al-Buraey, 1985). Islamic leadership is generally base on the primary and secondary resources of shariah (Al-Qur'an and Sunnah). Furthermore, ensuring essential elements such as cohesiveness, improved welfare of society, and smooth performance are important aspects of a leader's responsibility (Ali, 2009).

Leadership and subordinate have close relationship in obligation towards organizational performance. In Islamic perspectives, Safi (1995) proposed that leaders need to have good leadership qualities such as patience (sabr), conviction (yaqin), knowledge (' $\mathrm{ilm}$ ), communication (fathonah), enterprise (iqdam) and leniency (lin) in order to serve and guide their followers to achieve organization goals. Marbun (2013) also agree that trustworthiness, justice, sincerity, honesty, gratefulness and courage as Islamic leadership qualites that shows positive attributes in getting followers, customers and stakeholders confidence.

Deris (2012) emphasizes that quality of Islamic leadership consist of four main attributes; truthfulness (al-sidq), trust (amanah), knowledge (fathonah) and communication (tabligh). In addition, Deris also stressed that in order to achieve high organization performance, leadership qualities are important such as capability to understand proficiently, ability to respond questions sufficiently, ability to acquire love and warmth of the members, tendency to make decisions after consultation, encourage criticism, dynamic, serious and eager perception.

In this study, the quality of Islamic leadership is base on Al-Qur'an and Sunnah. There are four qualities of Islamic leadership that relate to Prophet Muhammad (SAW). It consists of truthfulness (al-sidq), trust (amanah), knowledge (fathonah) and communication (tabligh). All the qualities need to be implementing by Islamic leaders purposely for getting blessing from Allah (SWT). 


\subsubsection{Truthfulness (al-sidq)}

Truthfulness $(a l-s i d q)$ is one of the Islamic leadership qualities that required consistency between words and actions (Beekun \& Badawi, 1999). In Islamic leadership, truthfulness has comprehensive meanings. A leader should always speak truth and to be truthful from the core of heart, not for affectation but for the establishment of moral standards in the society. The character of sidq provides serenity to the soul, although lies will worry the heart and make it anxious. From the verses of Al-Qur'an stated that:

He did not utter the Qur'an of his own desire, the Qur'an from Allah to him through Gabriel who comes and recites it to him, and taught him (Al-Najm, 53: 4-5)

According to Abbasi (2008), there were three types of truthfulness (i) truthfulness of speaking; (ii) truthfulness of heart; and (iii) truthfulness of action. Truthfulness is needs in speech, intention, resolution, fulfillment of resolution, in action and in all stations on the path. Truth leads to consistent of organizational culture; reliable and responsible towards shareholders; customers and society as whole. Thus, truth is values that drive commitment of a leader and give better performance to the business.

\subsubsection{Trust (amanah)}

Trust as the expectation that employees in organization can be rely to fulfill their obligations, behave in a predictable conduct, and negotiate fairly even when the possibility of opportunism is present (Gulati \& Sytch, 2008). Trust is a value that should realized in leadership (Abbasi, Rehman \& Bibi, 2010). In order to implement this value in leadership means to make every staff a trustworthy person (Alhabshi \& Ghazali, 1994). Concept of trust stresses the idea of responsibility towards organizational stakeholders. As a core value, trust fits within the overall Islamic protocol governing social relationships (Beekun \& Badawi, 1999) and Prophet Muhammad (SAW) was the best example of trust leader.

I convey to you the messages of my Lord by explaining the commands and prohibitions (and for you a true adviser) warning you of Allah's torment and calling you to repentance and faith, and I am trustworthy in conveying the message of my Lord. It is also said that: you used to consider me a trustworthy person, so how is it that you are now accusing me (Al-A'raf, 7:68)

In global development, trust is a demand to sustain among business association. Lack of trustworthiness in organization's practices, will make lower possibility for other business to cooperate with the organization. The exhibition of trust is must for organization development (McGuire, Palus, Pasmore, \& Rhodes, 2009). Trust leads to reduce time consuming and cost which should be spent in matters of legal affairs. The confidentiality is also highlighted in Islamic teachings through prohibit of suspicious and distrust. Trust leads to save transaction time and cost that could be spent in negotiating and legal affairs. The right of privacy is also emphasized in the teaching of Islam through prohibition of suspicious.

\subsubsection{Knowledge (fathonah)}

Leaders expected to be knowledgeable and well informed (Safi, 1995; Bangash, 2000; Mustapha, 2000; Ahmad, 2002). Intensity in knowledge creates humbleness and persuades people how important the person needs to explore in the new knowledge areas. Al-Qur'an refers to it in a unique manner:

Those truly fear Allah (SWT), among His servants, who have knowledge, for Allah (SWT) is exalted in Might, Oft-forgiving (Fatir, 35:28)

The leadership notice that he or she needs to carry task that related in, economic, intellectual, political legal, education or military field acquire necessary specialized knowledge, skills and expertise (Safi, 1995). This knowledge brings competence and competent leaders have the ability to see full view of situation to deliver right outcomes at right time (Luthans, Youssef, \& Avolio, 2007). In organization, knowledge is valuable because it is the power to create difference and to provide competitive edge (Abbasi et al., 2010).

Muslim leaders must be knowledgeable in all aspects and it is important to the leaders in perform their tasks by following shariah and Islamic laws because they need to be capable of analyzing the overall situation, establishing priorities for action and developing strategies for their implementation in order to support the organizational performance and for the sake of Allah (SWT).

\subsubsection{Communication (tabligh)}

Communication (tabligh) is another leadership quality. It is the ability to articulate ideas and views with clarity and eloquence (Safi, 1995; Bangash, 2000). This is required to communicate the purpose of the mission clearly and to inspire people to follow it. Al-Qur'an itself is the most eloquent document and it appeals both to the mind and the heart. For example, Prophet Muhammad (SAW) delivered message of Islam in a way that instantly 
admitted by a small group of people in Makkah. Eventhough, the Quraish accepted that his message had value but they against it because they found it as undermining their personal interests (Volpato, 2011). Communication is an extremely important quality that needs to be learned, practice and master by every leader.

The messengers, Muhammad and other messengers, know that the angels have conveyed the message from Allah so that the jinn and human beings know that the messengers have conveyed the messages of their Lord. He has full knowledge of all the angels that surround them, (and He kept count of all things) it is also said that He knows their number just as He knows the state of the one who is wrapped up in his raiment (Al-Jinn, 72:28)

Communication is vital not only for convincing followers to accept the action and for giving themselves to a specific set of purposes, but for discussing and communicating with opponents and competitors as well (Abbasi, 2008).

\subsection{Quality of Islamic Leadership and Organizational Performance}

The ability to guide, influence and show the right way to others are the qualities of leadership (Majali, 1990). These qualities help in assisting Islamic leaders to be better, truthful, kind, practice moderation, and avoid being suspicious in dealing with their daily actions. A study by Hakim (2012) on Islamic leadership and performance among 268 employees in the Indonesian financial institution found that there is a significant effect between Islamic leadership and performance. Based on the result of his statistical analysis using Partial Least Square (PLS) method, Islamic leadership has an influence on organizational performance.

In addition, Dessler (2006) stated that the success of an organization depends greatly on the qualities of its leadership. In another study of Islamic leadership and managerial performance by Majeed, Khalid \& Khan, (2011), it was found that there is positive and significant relationship between Islamic leadership components (values/ethics and management by example) and organizational performance. All the dimensions give positive effect to the organizational performance. In general, organization can improve their performance by having good role model who follows the Islamic key attributes in order to seek Allah (SWT) blessing. It discovered that Islamic leadership practices exert a crucial influence of managerial performance (Abbasi, 2008).

\section{Methodology}

\subsection{Research Design}

This study will be used qualitative approach that specific on multiple case studies. Creswell (1994) defines qualitative research as an inquiry progression of understanding social or human issues, based on builds a complex, holistic depiction, figured with words, report detailed views of informants, and conducted in a natural situation. In addition, Yin (1989) defined a case study as empirical inquiry that examines a contemporary phenomenon within real-life context when the borders between phenomenon and context are ambiguous evident and in which various sources of evidence are used. These definitions will use to guide through the implementation of the study.

Yin (2003) differentiated several types of case study such as descriptive, explanatory and exploratory. In this study, the relevant type of case study is explanatory. An explanatory case study defined as relationship between cause and effect, and clarifying how the events take place (Yin, 1989). According to Imas (2009), the explanatory case study investigates link among variables and usually involves multi-method considerations. In addition, it also examines process and procedure at several places. Explanatory case studies are valuable when conducting causal research study. Mostly in-complicated studies of institutions or organizations that need researcher to employ several cases to examine a plurality of influences. Thus, this study will be investigated the qualities of Islamic leadership that might influence organizational performance within Takaful industry in Malaysia.

\subsection{Population and Sample}

The unit of analysis precise whether the intensity of research will focus on the data collection about individual, groups, organizations, movements, institutions and countries (Neuman, 2006; Zikmund, 2003). In this study, the unit of analysis will be the organization. Malaysia will select as the country to investigate and the sector to examine will be the Takaful industry. There are 11 Takaful operators licensed by Bank Negara Malaysia and the interviews will focus on top management Islamic leaders in Malaysian Takaful industry.

\subsection{Data Collection}

A case study design enables the researcher to determine if the leaders in Takaful companies were aware of the qualities of Islamic leadership that will affect organizational performance. This study will use a semi-structured interview process, observation and document analysis, where the researcher was the key instrument for data 
collection (Merriam, 2009). The data will collect through 11 organizations that represent a leader as interviewee, face-to-face and semi-structured interviews (Fontana \& Frey, 1994).

The purpose of semi-structured interview is to understand and being present with the informants in order to build confidence between researcher and subject (Fowler, 1993; Fontana \& Frey, 1994). Moreover, interview is a data collection method that includes observation, visual cues and self-administered sections (Fowler, 1993). Finally, the face-to-face interviews might result in a higher response rate than questionnaires (Fink \& Kosecoff, 1985).

Next, observation can be useful mode of data collection and it is a form of primary data to be highly valued (Yin, 2011). An effective qualitative researcher must be good observers and listeners, as well as noting the silences, whether in interviews, observations, or documents, is an important component of being a good listener (Merriam, 1988).

In combination with interviews and observation, the researcher will review relevant documents to support multiple of data. The purpose of document analysis is to have good fortune of reviewing many information of specific organization (Yin, 2011). Relevant documents will most likely include letters, reports, job descriptions and performance expectations, newsletters and intranet data sources, and artifacts from participant workspaces (Willet, 2009).

\subsection{Data Analysis}

The data from interviews will analyze using the Atlas.ti (version 7) software program. Atlas.ti (version 7) supports in the process of qualitative analyzing data collection through unstructured and semi-structured data collection methods. This software keeps the researcher very close to the data permitting for strong and rich exploration and discovery.

The software functions includes of open-ended data, audio files, images, videos, or Google Earth images. It involves the narrative and consideration of researchers' points of view. It is also entails the different data collection methods such as in-depth interviews, semi-structured interviews, field notes, surveys with open-ended questions and multi-media analysis. It stresses on qualitative, rather than quantitative analysis, such as determining the elements that comprise the primary data material and interpreting their meaning (Friese, 2013).

\subsection{Ethical Consideration}

Ethical dilemmas exist when interviews, observations, and surveys are use as data collection methods in qualitative research studies (Merriam, 1988). One of the most important ways to act in an ethical manner is to ensure the protection of the participants in a research study.

Referring to Gradwell (2004), the following guidelines were used to protect each participant's rights. These consist of i) the research objectives were clearly eloquent verbally and in writing so that it was clearly understood by the participant; ii) written consent to continue with the study as articulated was received from the participant; iii) the participants were notified of all data collection mechanisms and activities; iv) verbatim transcriptions, written analysis and reports were obtainable to the participant; v) the participant's rights, concerns and wishes were priority when choices are made regarding the data report, and vi) the final result regarding the participant secrecy rests with the participant.

\section{Expected Findings}

Results of the study expected to be positively demonstrating the importance of quality of Islamic leadership towards organizational performance. This study contributes to Islamic Leadership Theory by examining the quality of Islamic leadership and organizational performance. It will extend the theory by examining how quality of Islamic leadership factors influences the organizational performance. In addition, this study has also contributed to the existing literature on leadership by highlighting the quality of Islamic leadership and examining the effect of truthfulness (al-sidq), trust (amanah), knowledge (fathonah) and communication (tabligh) which are based on Al-Qur'an and hadtih towards performance as a new concept for the management discipline. This could enhance academics' understanding regarding the attributes of Islamic leadership in improving organizational performance.

The practical expected result of the study is focus on management and leadership within organization. Leaders should adapt Islamic leadership qualities in order to increase the organizational performance. This study gives an idea to a managerial that truthfulness (al-sidq), trust (amanah), knowledge (fathonah) and communication (tabligh) act as a tool in helping the organizations to continue interacts with stakeholders, establishes new and strong partnerships, identify future opportunities and develop the capabilities to increase organizations performance. The study also will verify that the existence quality of Islamic leadership will effect organizational 
performance. The expected findings will reveal that the organizational performance can enhance by stimulating the quality of Islamic leadership. High performance of organization will contribute to a greater job satisfaction, lower employee turnover, higher productivity, and better decision making in organization. It also affects the entire organizations' internal social structures and increase efficiency (Evans \& Davis, 2005).

\section{Conclusions}

In order to remain in business and perform well, organizations need to focus on their leadership. Given the contribution of the financial services sector to Malaysia's economic growth and the rise in banking and Islamic investment including insurance/takaful, the management of the organizations associated with this sector need to put more attention on the quality of Islamic leadership. Since Malaysia is currently the third largest Takaful market at the global level, more weight should be place on increasing the performance of this industry. Therefore, Takaful operators should realize the importance of Islamic leadership qualities as a predictor of organizational performance.

\section{References}

Aabed, A. (2005). A study of Islamic Leadership Theory and practice in K-12 Islamic schools in Michigan (Unpublished doctoral thesis). University of Brigham Young, United States. Retrieved from $\mathrm{http} / / /$ scholarsarchive.byu.edu/cgi/viewcontent.cgi? article=1407\& context=etd

Abbasi, A. S. (2008). Role of Islamic leadership in value based corporate management (Unpublished doctoral thesis). National University of Modern Language, Islamabad. Retrieved from prr.hec.gov.pk/thesis/314s.pdf

Abbasi, A. S., Rehman, K. U., \& Bibi, A. (2010). Islamic management model. African Journal of Business Management, 4(9), 1873-1882.

Ahmad, A. (2002). Islamic leadership for the 21st century. Paper presented at the IGS-ICOJ International Conference on leadership and unity in Islam at Kobe, Japan.

Al-Buraey, M. (1985). Administrative development: An Islamic perspective. London, UK: KPI

Alhabshi, S. O., \& Ghazali, A. H. (1994). Islamic values and management. Selangor: Institute of Islamic Understanding Malaysia.

Ali, A. J. (2009). Islamic perspectives on leadership: A model. International Journal of Islamic and Middle Eastern Finance and Management, 2(2), 160-180. http://dx.doi.org/10.1108/17538390910965167

Al-Quran. (Ed.).

Altalib, H. (1991). Training guide for Islamic workers. Herndon, Virgina: IIIT\&IIFSO.

Armfield, I. W. (2005). Aligning federal human resources departments with organizational goals and objectives to enhance performance in the public sector (Unpublished doctoral dissertation). University of Phoenix, United States.

Ather, S. M., \& Sobhani, F. A. (2007). Managerial leadership: An Islamic perspective. IIUC Studies, 4, 7-24. http://dx.doi.org/10.3329/iiucs.v4i0.2688

Bangash, Z. (2000). The concepts of leader and leadership in Islam. Retrieved November 27, 2012, from $\mathrm{http}: / /$ www.islamicthought.org/pp-zb-leader.html

Beck, T., \& Webb, I. (2003). Economic, demographic and institutional determinants of life insurance consumption across countries. World Bank Economic Review, 17(1), 51-88. http://dx.doi.org/10.1093/ wber/lhg011

Beekun, R., \& Badawi, J. (1999). The leadership process in Islam. Beltsville, MD: Amana Publications.

Behery, M. H., \& Paton, R. A. (2008). Performance appraisal-cultural fit: Organizational outcomes within the UAE. Education, Business and Society: Contemporary Middle Eastern Issues, 1(1), 34-49. http://dx.doi.org/10.1108/17537980810861501

Bougae, C. (2005). A descriptive study of the impact of executive coaching from the perspective of executive leader (Unpublished doctoral thesis). University of Capella, United States. Retrieved from http://sunzi.lib.hku.hk/ER/detail/hkul/3514397

Browne, M. J., \& Kim, K. (1993). An international analysis of life insurance demand. Journal of Risk and Insurance, 60, 616-634. http://dx.doi.org/10.2307/253382

Chowdbury, N. (2002). Leadership strategies and global unity for the 21st century: An Islamic perspective. 
Paper presented at the IGS-ICOJ International Conference on leadership and unity in Islam, Kobe, Japan.

Creswell, J. W. (1994). Research design: Qualitative and quantitative approaches. Thousand Oaks, London: Sage.

Delaney, J. T., \& Huselid, M. A. (1996). The impact of human resource management practices on perceptions of organizational performance. The Academy of Management Journal, 39(4), 949-969. http://dx.doi.org/ $10.2307 / 256718$

Deris, S. M. (2012). Commentary on seerah and history. Retrieved November 26, 2013, from http://smderis.blogspot.com/2012/05/muhammad-intelligent-prophet-four.html

Dessler, G. (2006). A framework for human resource management. Upper Saddle River, NJ: Prentice Hall.

Economic Transformation Programme. (2012). Financial services - EPP 10: Becoming the indisputable global hub for Islamic finances. Retrieved May 13, 2013, from http://etp.pemandu.gov.my/FinancialServices -@-Financial_Services_-_EPP_10-;Becoming_the_indisputable_global_hub_for_Islamic_finances.aspx

Enz, R. (2000). The s-curve relation between per-capita income and insurance penetration. Geneva Papers on Risk and Insurance: Issues and Practice, 25(3), 396-406. http://dx.doi.org/10.1111/1468-0440.00072

Ernst, \& Young. (2012). Industry growth and preparing for regulatory change: The World Takaful Report 2012. Dubai: Mega.

Evans, W. R., \& Davis, W. D. (2005). High-performance work systems and organizational performance: The mediating role of internal social structure. Journal of Management, 31, 758-775. http://dx.doi.org/ $10.1177 / 0149206305279370$

Fink, A., \& Kosecoff, J. (1985). How to conduct surveys: A step-by step guide. Newbury Park: Sage Publications.

Fontana, A., \& Frey, J. H. (1994). Interviewing. The art of science. In N. K. Denzin, \& Y. S. Lincoln (Eds.), Handbook of Qualitative Research. Thousand Oaks: Sage.

Fowler, F. J. (1993). Survey research methods (2nd ed.). Newbury Park: Sage Publications.

Friese, S. (2013). Atlas.ti 7: User guide and reference. Berlin: ATLAS.ti Scientific Software Development $\mathrm{GmbH}$, Berlin. Retrieved from http://www.atlasti.com/uploads/media/atlasti_v7_manual_201312.pdf

Fukuyama, F. (1995). Trust: The social virtues and the creation of prosperity. London: Hamish Hamilton.

Gilley, J. W., \& Maycunich, A. (2000). Organizational learning, performance, and change: An introduction to strategic human resource development. Cambridge, MA: Perseus Books.

Gradwell, S. S. (2004). Communicating planned change: A case study of leadership credibility (Unpublished doctoral Thesis). University of Drexel, United States.

Gulati, R., \& Sytch, M. (2008). Does familiarity breed trust? Revisiting the antecedents of trust. Managerial and Decision Economics, 29, 165-190. http://dx.doi.org/10.1002/mde.1396

Hakim, A. (2012). The implementation of Islamic leadership and Islamic organizational culture and its influence on Islamic working motivation and Islamic performance PT Bank Mu'amalat Indonesia Tbk. Employee in the Central Java. Asia Pacific Management Review, 17(1), 77-90. http://dx.doi.org/10.6126/APMR. 2012.17.1.05

Halim, N. (2012). Islamic finance news: The Takaful and re-Takaful industry. Retrieved January 15, 2013, from http://www.islamicfinancenews.com/2012_supplement/2012takaful/Takaful.pdf

Halim, N. (2013). Islamic finance news: Takaful \& re-Takaful, baking on Asia. Retrieved July 14, 2013, from http://www.islamicfinancenews.com/2013_supplement/takaful2013/takaful2013.pdf

Hamid, M. A., \& Rahman, N. M. N. A. (2011). Commitment and performance: A case of Takaful (Islamic Insurance) representatives in Malaysia. Australian Journal of Basic and Applied Sciences, 5(10), 777-785.

Hashim, A. J., \& Khairuddin, M. H. (2012). Exploring the leadership styles among Takaful agency leaders. Paper presented at the Proceeding: International Conference on Islamic Leadership-2 (ICIL), Kuala Lumpur, Malaysia.

Imas, L. M. (2009). Designing and conducting case studies for development evaluations. Paper presented at the A Preconference Workshop for the IDEAS Global Assembly, Johannesburg, South Africa.

Ismail, N., Alhabshi, S. O., \& Bacha, O. I. (2011). Organizational form and efficiency: The coexistence of family 
Takaful and life insurance in Malaysia. Paper presented at the 2nd International Conference on Business and Economic Research, 14-16 March 2011, Langkawi, Malaysia.

Kasturi, R. (2006). Performance management in insurance corporation. Journal Business Administration Online, $5(1), 157-163$.

Kazmi, A. (2007). Managing from Islamic perspectives: Some preliminary findings from Malaysian Muslim-managed organizations. Paper presented at the International Conference, Management from Islamic Perspective at Kuala Lumpur, Malaysia.

Luthans, F., Youssef, C., \& Avolio, B. (2007). Psychological capital: Developing the human competitive edge. USA: Oxford University Press.

Mahadi, N. (2011). The role of emotional intelligence in the quality of leader-follower relationship (Unpublished doctoral thesis). University of Southampton, England. Retrieved from eprints.soton.ac.uk/210541/

Majali, A. S. (1990). A proposal for the establishment of an Islamic leadership institution. Journal Islamic Academic Science, 3(4), 251-254. Retrieved from http://www.medicaljournal-ias.org/.../Belge/MajaliCXQ MVBKGYU78235.pdf

Majeed, Y., Khalid, Z., \& Khan, M. A. (2011). The impact of Islamic leadership on organizational Objectives. Far East Journal of Marketing and Management, 1(1), 54-65. Retrieved from ideas.repec.org/a/fej/artcal/ v1y2011i5p54-65.html

Marbun, D. S. (2013). Attributions and requirements of Islamic leadership. Management Research Review, 36(4), 379-387. http://dx.doi.org/10.1108/01409171311314987

McGuire, J. B., Palus, C. J., Pasmore, W., \& Rhodes, G. B. (2009). Transforming your organization. On Global Organizational Development White Paper Series: Center for Creative Leadership.

Merriam, S. B. (1988). Case study research in education: A qualitative approach. San Francisco: Jossey-Bass Publishers.

Merriam, S. B. (2009). Qualitative research: A guide to design and implementation. San Francisco: John Wiley and Sons.

Mudaki, A. L., Wanjere, D., Ochieng, I., \& Odera, O. (2012). Effects of operational factors on organizational performance in Kenyan insurance industry. International Journal of Business and Social Science, 3(17), 237-241. Retrieved from ijbssnet.com/journals/Vol_3_No_17_September_2012/27.pdf

Mustapha, A. O. (2000). Leadership qualities in Islam. Retrieved December 4, 2012, from http://www.jpa.gov.my/buletinjpa/j2bil1/leadership\%20qualities\%20in\%20Islam.htm

Neuman, W. L. (2006). Social research methods: Qualitative and quantitative approaches (6th ed.). Boston: Pearson Education Inc.

Rahman, Z. A. (2009). Takaful: Potential demand and growth. Islamic Economy, 22(1), 55-72. Retrieved from kantakji.com/media/2728/d267.pdf

Ricardo, R., \& Wade, D. (2001). Corporate performance management: How to build a better organization through measurement driven strategies alignment. New York: Taylor \& Francis.

Saad, N. M. (2012). An analysis on the efficiency of Takaful and insurance companies in Malaysia: A non-parametric approach. Review of Integrative Business Economy Research, 1(1), 33-56. Retrieved from irep.iium.edu.my/.../1/Takaful_Efficiency_RIBER2012-080_33-56.pdf

Saad, N. M., Majid, M. S. A., Yusof, R. M., Duasa, J., \& Rahman, A. R. A. (2006). Measuring efficiency of insurance and Takaful companies in Malaysia using data envelopment analysis (DEA). Review of Islamic Economics, 10(2), 5-26. Retrieved from http://www.mbri.ac.ir/userfiles/file/Islamic\%20Banking/\%D8\%A8\% D8\%A7\%D9\%86\%DA\%A9\%20\%D9\%85\%D9\%82\%D8\%A7\%D9\%84\%D8\%A7\%D8\%AA/Takaful/Meas uring $\% 20 \mathrm{Ef} \% \mathrm{EF} \% \mathrm{AC} \% 81$ ciency\%20of $\% 20$ Insurance $\% 20$ and $\% 20$ Takaful.pdf.

Safi, L. (1995). Leadership and subordination: An Islamic perspective. The American Journal of Islamic Social Sciences, 12(2), 204-223. Retrieved from http://i-epistemology.net/attachments/930_v12n2\%20-\%20 Safi\%20-\%20Leadership\%20and\%20Subordination.pdf.

Scott, W. R. (2003). Organizations: Rational, natural, and open systems (5th ed.). Upper Saddle River, NJ: Prentice Hall.

Shen, W., \& Cannella, A. A. J. (2002). Revisiting the performance consequences of CEO succession: The 
impacts of successor type, postsuccession senior executive turnover, and departing CEO tenure. Academy of Management Journal, 45(4), 717-733. http://dx.doi.org/10.2307/3069306

Shooshtarian, Z., \& Amini, M. (2012). The study of relationship between leaders' behavior and efficiency and return on investment. Polish Journal of Management Studies, 6, 55-67. Retrieved from http://EconPapers. repec.org/RePEc:pcz:journl:v:6:y:2012:i:1:p:55-67

Toor, S. R. (2008). Merging spirituality and religion: Developing an Islamic Leadership Theory. IIUM Journal of Economics and Management, 16(1), 15-46.

Venkatraman, N., \& Ramanujam, V. (1986). Measurement of business performance in strategy research: A comparison of approaches. Academy of Management Review, 1(4), 801-808. http://dx.doi.org/10.2307/ 258398

Volpato, N. (2011). What does Islam say about leadership? Retrieved December 23, 2012, from http://um-bs.com/2011/02/06/what-does-islam-say-about-leadership/

Willet, S. R. (2009). Organizational climate, transformational leadership and leading organizational change: A study of senior business leaders in the life insurance industry (Unpublished doctoral dissertation). University of Capella, United States. Retrieved from http://gradworks.umi.com/33/87/3387853.html

Yazid, A. S., Arifin, J., Hussin, M. R., \& Daud, W. N. W. (2012). Determinants of family Takaful (Islamic life insurance) demand: A conceptual framework for a Malaysian Study. International Journal of Business and Management, 7(6), 115-127. http://dx.doi.org/10.5539/ijbm.v7n6p115

Yin, R. K. (1989). Case study research: Design and methods. London: Sage.

Yin, R. K. (2003). Applications of case study research (2nd ed.). United State: Sage Publications.

Yin, R. K. (2011). Qualitative research from start to finish. New York: The Guilford Press.

Yon, B. W. A. (2004). Takaful - An option to conventional insurance: A Malaysian model. Retrieved January, 20th, 2013, from http://www.takaful.coop/doc-store/takaful

Zikmund, W. G. (2003). Business research methods (7th ed.). Ohio: Thomson Learning.

\section{Copyrights}

Copyright for this article is retained by the author(s), with first publication rights granted to the journal.

This is an open-access article distributed under the terms and conditions of the Creative Commons Attribution license (http://creativecommons.org/licenses/by/3.0/). 